\title{
PENINGKATAN HASIL BELAJAR IPA DENGAN MENGGUNAKAN PENDEKATAN KONSTRUKTIVISME PADA SISWA KELAS IV SD NEGERI 09 IV KOTO AUR MALINTANG KABUPATEN PADANG PARIAMAN
}

\section{Misniati}

\section{Abstrak}

Penelitian dilatarbelakangi dari kenyataan di Sekolah Dasar bahwa pembelajaran sering didominasi oleh guru sebagai sumber informasi. Berdasarkan pengamatan peneliti pada tanggal 5 Maret 2015 ditemukan hasil belajar IPA siswa masih rendah, untuk itu peneliti melalui penelitian tindakan kelas ini ingin mencoba meningkatkan hasil belajar IPA dengan menggunakan pendekatan konstruktivisme pada siswa kelas IV SD Negeri 09 IV Koto Aur Malintang Kabupaten Padang Pariaman. Pendekatan yang digunakan adalah pendekatan kualitatif yang terdiri dari dua siklus meliputi empat tahap yaitu perencanaan, tindakan, pengamatan,refleksi. Data penelitian ini berupa informasi tentang proses dan data hasil tindakan yang diperoleh dari hasil pengamatan, hasil wawancara, dan tes. Subjek peneliti adalah guru dan siswa kelas IV yang berjumlah 36 orang. Analisis data dilakukan dengan menggunakan model analisis data kualitatif dan kuantitatif. Penilaian yang digunakan dalam pengumpulan data adalah penilaian proses (afektif dan psikomotor), penilaian hasil (kognitif) dan rambu-rambu lembaran pengamatan penggunaan pendekatan konstruktivisme dari aspek guru dan siswa. Untuk mengetahui peningkatan hasil belajar siswa diadakan tes yang dianalisis dengan menggunakan penilaian dengan tolok ukur keberhasilan kelas minimal 75\%. Hasil belajar siswa dengan menggunakan pendekatan konstruktivisme pada siklus I dan II mengalami peningkatan di mana nilai rata-rata pada siklus I diperoleh rata-rata 73 dan pada siklus II rata-rata 83. Dengan demikian dapat disimpulkan bahwa pembelajaran IPA dengan menggunakan pendekatan konstruktivisme dapat meningkatkan hasil belajar IPA siswa kelas IV SD Negeri 09 IV Koto Aur Malintang Kabupaten Padang Pariaman.

Keyword: IPA, Konstruktivismen

Copyright (C) 2016 IICET (Padang - Indonesia) - All Rights Reserved

Indonesian Institute for Counseling, Education and Theraphy (IICET)

\section{PENDAHULUAN}

IPA sebagai salah satu mata pelajaran di SD merupakan program untuk menanamkan dan mengembangkan pengetahuan, keterampilan, dan sikap nilai ilmiah pada siswa, serta rasa mencintai dan menghargai kebesaran Tuhan Yang Maha Esa. Adapun tujuan pelajaran IPA di SD yaitu agar setiap siswa memiliki kemampuan, sebagaimana yang telah dijabarkan dalam BSNP (KTSP 2006: 484) antara lain: 1) Memperoleh keyakinan terhadap kebesaran Tuhan Yang Maha Esa berdasarkan keberadaan, keindahan, dan keteraturan alam ciptaan-Nya, 2) mengembangkan pengetahuan dan pemahaman konsep-konsep IPA yang bermanfaat dan dapat diterapkan dalam kehidupan sehari-hari, 3) mengembangkan sikap rasa ingin tahu sikap positif tentang adanya hubungan yang saling mempengaruhi dan kesadaran tentang adanya hubungan yang saling mempengaruhi antara IPA, lingkungan, teknologi, dan masyarakat, 4) mengembangkan keterampilan proses untuk menyelidiki alam sekitar dan memecahkan masalah dan membuat keputusan, 5) meningkatkan kesadaran untuk berperan serta dalam memelihara, menjaga, dan melestarikan lingkungan alam, 6) meningkatkan kesadaran untuk menghargai alam dan segala keteraturannya sebagai salah satu ciptaan Tuhan, 7) memperoleh bekal pengetahuan, konsep, dan keterampilan IPA sebagai dasar untuk melanjutkan pendidikan ke SMP/MTs.

Untuk meningkatkan hasil belajar siswa dalam pembelajaran IPA, siswa perlu dibiasakan memecahkan masalah, menemukan sendiri, dan bergelut dengan ide-ide, pengetahuan yang diperoleh dengan cara menghapal hanya mampu bertahan dalam jangka waktu pendek, sedangkan pengetahuan yang didapat dari "menemukan sendiri" mampu bertahan lama dan proses belajarnya akan lebih bermakna bagi siswa. 
BSNP (2006:484) menyatakan bahwa: "pendidikan IPA merupakan proses pembelajaran yang menekankan pada pemberian pengalaman secara langsung untuk mengembangkan kompetensi agar menjelajahi dan memahami alam sekitar secara ilmiah".

Berdasarkan observasi dan wawancara yang penulis lakukan pada tanggal 5 Maret 2015, hasil belajar siswa kelas IV di SD Negeri 09 IV Koto Aur Malintang Kabupaten Ppadang Pariaman untuk pembelajaran IPA masih belum memuaskan. Hal ini dapat dilihat dari data nilai Ulangan Harian I IPA semester II, Tahun ajaran 2014/2015, di mana nilai rata-rata siswa diperoleh 55 atau masih berada di bawah standar minimal yang ditetapkan oleh sekolah yaitu 70 .

Hal ini disebabkan dalam proses pembelajaran IPA, masih didominasi oleh penggunaan metode ceramah dan kegiatannya lebih berpusat pada guru. Aktifitas siswa hanya mendengarkan penjelasan guru dan mencatat hal-hal yang dianggap penting. Artinya, guru lebih banyak menguasai proses pembelajaran. Guru juga terlihat belum menggunakan media pembelajaran yang optimal. Dan saat pembelajaran IPA berlangsung, siswa tidak berani bertanya kepada guru karena guru kurang memotivasi siswa untuk bertanya meskipun ada materi pelajaran yang tidak dimengerti. Guru jarang mengaitkan pembelajaran dengan hal-hal yang nyata di sekitar siswa, sehingga siswa lebih banyak mendengar dan menunggu sajian guru dari pada mencari dan menemukan sendiri pengetahuan serta keterampilan yang mereka butuhkan. Hasilnya, siswa memang memiliki banyak pengetahuan, akan tetapi siswa tidak dilatih untuk menemukan sendiri pengetahuan itu, dan tidak dilatih untuk mengembangkan ilmu pengetahuan itu secara mandiri.

Masalah penelitian dirumuskan sebagai berikut "Bagaimanakah meningkatkan hasil belajar IPA dengan menggunakan pendekatan konstruktivisme pada siswa kelas IV SD Negeri 09 IV Koto Aur Malintang Kabupaten Padang Pariaman?.

Tujuan penelitian ini adalah sebagai berikut

1. Mendeskripsikan rencana pelaksanaan pembelajaran IPA dalam meningkatkan hasil belajar IPA dengan menggunakan pendekatan konstruktivisme pada siswa kelas IV SD Negeri 09 IV Koto Aur Malintang Kabupaten Padang Pariaman

2. Mendeskripsikan pelaksanaan pembelajaran dalam meningkatkan hasil belajar IPA dengan menggunakan pendekatan konstruktivisme pada siswa kelas IV SD Negeri 09 IV Koto Aur Malintang Kabupaten Padang Pariaman

3. Mendeskripsikan hasil belajar IPA siswa setelah menggunakan pendekatan konstruktivisme pada siswa kelas IV SD Negeri 09 IV Koto Aur Malintang Kabupaten Padang Pariaman?

Hasil penelitian ini diharapkan dapat bermanfaat dalam memberikan masukan, terutama bagi:

1. Guru, sebagai pertimbangan untuk menggunakan pendekatan konstruktivisme dalam pembelajaran IPA pada siswa kelas IV SD Negeri 09 IV Koto Aur Malintang Kabupaten Padang Pariaman

2. Siswa, dapat meningkatkan pemahaman siswa terhadap pembelajaran IPA serta dapat meningkatkan hasil belajar siswa.

\section{METODELOGI PENELITIAN}

Penelitian tindakan kelas ini telah dilaksanakan di kelas IV SD Negeri 09 IV Koto Aur Malintang Kabupaten Padang Pariaman. Lokasi ini dipilih sebagai tempat penelitian dengan pertimbangan sebagai berikut:

a. Belum pernah dilaksanakannya pembelajaran IPA dengan menggunakan pendekatan konstruktivisme.

b. Peneliti bertugas di sekolah ini.

Adapun yang telah menjadi subjek penelitian adalah siswa kelas IV SD Negeri 09 IV Koto Aur Malintang, dengan jumlah siswa 36 orang, yang terdiri dari 12 siswa laki-laki dan 24 siswa perempuan. Pada pembelajaran IPA dengan Kompetensi Dasar menjelaskan pengaruh perubahan lingkungan fisik terhadap daratan (erosi, abrasi, banjir, dan longsor)"Semester II Tahun Pelajaran 2014/2015

Penelitian ini telah dilaksanakan pada bulan April sampai dengan Juni 2015, pada Semester II tahun pelajaran 2014/2015 dalam pembelajaran IPA dengan materi pokok perubahan lingkungan (erosi, abrasi, banjir, longsor) dalam pembelajaran IPA.

Penelitian ini merupakan penelitian tindakan kelas dengan menggunakan pendekatan kualitatif. Pendekatan ini berkenaan dengan perbaikan atau peningkatan proses pembelajaran pada suatu kelas. Oleh Sebab itu penelitian yang dilaksanakan berasal dari persoalan praktek pembelajaran di kelas secara lebih profesional.

Penelitian tindakan kelas yang dilaksanakan menggunakan model siklus yang dikembangkan oleh Kemmis dan Taggart (1990:11) yaitu mempunyai empat tahap yaitu perencanaan, tindakan, pengamatan, dan refleksi. Penelitian ini telah dilaksanakan dalam dua siklus yaitu siklus I dan siklus II. Setiap siklus 
dilaksanakan dua kali pertemuan. Dan setiap siklus dilakukan pengamatan terhadap aktivitas siswa selama proses pembelajaran yaitu selama 4x35 menit. Pada akhir setiap siklus dilakukan tes hasil belajar.

Data penelitian berupa data primer yang diperoleh dari hasil pengamatan, wawancara, catatan lapangan dari setiap tindakan penggunaan pendekatan konstruktivisme pada pembelajaran IPA: menjelaskan pengaruh perubahan lingkungan fisik terhadap daratan (erosi, abrasi, banjir, dan longsor) dengan pendekatan konstruktivisme di kelas IV Sekolah Dasar yang diteliti. Data tersebut berisi hal-hal yang berkaitan dengan perencanaan, pelaksanaan dan hasil pembelajaran/

Sumber data penelitian adalah proses pembelajaran IPA tentang menjelaskan pengaruh perubahan lingkungan fisik terhadap daratan (erosi, abrasi, banjir, dan longsor) yang meliputi perencanaan pembelajaran, pelaksanaan pembelajaran, evaluasi pembelajaran, serta kegiatan wawancara dengan guru. Data tersebut diperoleh dari subjek yang terteliti, yaitu siswa kelas IV SD Negeri 09 IV Koto Aur Malintang beserta peneliti.

Data penelitian ini dikumpulkan dengan menggunakan lembaran pengamatan atau observasi, dokumentasi dan hasil tes.

Data yang diperoleh dalam penelitian dianalisis dengan menggunakan model analisis data kualitatif dengan model teknik analisis interaktif yang dikembangkan oleh Miles dan Huberman (dalam Kunandar, 2008:101), di mana analisis interaktif ini terdiri atas tiga komponen kegiatan yang saling terkait satu sama lain yaitu dimulai dengan reduksi data, pembeberan data sampai pada penarikan kesimpulan.

Joko (2006:106), menjelaskan analisis data kualitatif dilakukan terhadap data baik berupa data kualitatif maupun data kuantitatif. Terhadap data kualitatif dalan hal ini dilakukan terhadap data yang berupa informasi, uraian yang berupa penjelasan-penjelasan yang tersaji dalam catatan lapangan. Sedangkan terhadap data kuantitatif yaitu data dalam bentuk jumlah dituangkan untuk menerangkan suatu kejelasan dari angkaangka sehingga memperoleh gambaran baru, kemudian dijelaskan kembali dalam bentuk kalimat/uraian.

Analisis ini dimulai dengan mereduksi data berdasarkan masalah yang diteliti, diikuti dengan penyajian data dan terakhir menyimpulkan dan verifikasi. Tahap analisis yang demikian dilakukan berulang-ulang, begitu data selesai dikumpulkan pada setiap tahap pengumpulan data dalam setiap tindakan.

Untuk mengetahui hasil observasi dapat dianalisis dengan menggunakan format observasi dalam bentuk lembaran pengamatan. Lembaran pengamatan berisi segala kegiatan yang dilakukan oleh guru maupun siswa yang terdapat dalam lampiran. Sedangkan untuk mengetahui peningkatan Hasil belajar siswa, Kasbolah (dalam Theresia, 2008:8) dapat dianalisis dengan menggunakan penilaian dengan tolok ukur keberhasilan minimal 75\% siswa mencapai nilai 70. Target/ tolok ukur keberhasilan ini menentukan jumlah/ banyaknya siklus yang dilaksanakan.

\section{HASIL DAN PEMBAHASAN PENELITIAN Hasil Penelitian}

1. Siklus I

Siklus I dilaksanakan dalam dua kali pertemuan. Selama pembelajaran berlangsung, peneliti dibantu oleh guru kelas IV mengadakan pengamatan dengan menggunakan lembar pengamatan yang telah disiapkan.

Pembelajaran siklus I difokuskan pada materi perubahan lingkungan fisik yang disebabkan oleh erosi dan abrasi dengan menggunakan pendekatan konstruktivisme. Untuk memperoleh data tentang pelaksanaan siklus I dilakukan pengamatan, tes hasil belajar. Hasil pengamatan, tes selama pelaksanaan tindakan dianalisis dan didiskusikan dengan pengamat sehingga diperoleh hal-hal sebagai berikut:

1) Pembelajaran yang dilaksanakan telah mencerminkan dengan menggunakan pendekatan konstruktivisme, karena secara umum proses pembelajaran berjalan sesuai dengan rencana yang telah disusun.

2) Hasil pengamatan yang dilakukan guru kelas IV selaku pengamat terhadap aktivitas guru dalam kegiatan pembelajaran pertemuan pertama siklus I ini mencapai kriteria keberasilan $73 \%$ yang berarti masuk kategori cukup dan kita lihat tingkat aktifitas siswa dalam kegiatan pembelajaran mencapai kriteria keberhasilan 68\%, ini berarti masuk kategori kurang. Sedangkan hasil pengamatan terhadap aktifitas guru pada pertemuan kedua siklus I mencapai kriteria keberhasilan $82 \%$ yang termasuk dalam kategori baik dan pada hasil pengamatan pada kegiatan siswa mencapai kriteria keberhasilan $76 \%$ yang berarti masuk kategori cukup.

3) Siswa belum terbiasa melakukan pembelajaran dalam bentuk diskusi kelompok sehingga dalam pembagian kelompok masih banyak yang meribut dan saling memilih teman.

4) Masih banyak siswa yang belum aktif dalam kerja kelompok.

5) Kurang adanya siswa yang menanggapi hasil diskusi yang dilaporkan temannya. 
6) Hasil belajar siswa yang dicapai sudah baik, dimana hasil tes akhir yang dilakukan pada siklus I didapatkan nilai rata-rata siswa adalah 73 dan secara klasikal siswa mencapai tingkat ketuntasan $61 \%$ sedangkan tingkat ketuntasan kelas yang diharapkan $75 \%$.

Berdasarkan pengamatan dan tes yang dilakukan, dapat disimpulkan bahwa aktifitas guru dan siswa belum mencapai kategori keberhasilan yang ditetapkan, di mana masih banyaknya siswa yang belum aktif dalam pembelajaran. Inisiatif siswa dari dalam diri sendiri masih kurang untuk mengikuti pembelajaran dengan baik.

Dengan demikian peningkatan hasil belajar IPA dengan menggunakan pendekatan konstruktivisme akan peneliti lanjutkan pada siklus II dengan lebih baik sesuai dengan langkah-langkah yang telah direncanakan. Pelaksanaan siklus II diharapkan dapat berjalan baik dengan memperhatikan hal-hal sebagai berikut:

1) Peneliti selaku guru lebih memperhatikan lagi langkah-langkah pembelajaran yang terdapat dalam RPP, agar hasil pengamatan terhadap aktifitas guru dan siswa lebih meningkat lagi dan menuju kearah yang sempurna.

2) Peneliti selaku guru harus menggunakan kalimat yang sederhana dalam melakukan pelaksanaan pembelajaran sehingga siswa mudah memahami apa yang disampaikan guru.

3) Peneliti selaku guru dalam pembagian kelompok lebih teliti lagi sehingga kerja sama dalam kelompok lebih terwujud dan pembagian kelompoknya lebih diperhatikan lagi.

4) Peneliti selaku guru harus meningkatkan bimbingan kepada siswa dalam mengerjakan tugas kelompok agar siswa lebih mengerti tentang apa yang akan dikerjakan siswa dalam kelompok serta memberikan penilaian pribadi sehingga guru dapat mengetahui siswa mana yang aktif dan yang tidak aktif.

5) Peneliti selaku guru lebih giat memancing siswa dengan pertanyaan-pertanyaan yang membimbing siswa untuk mengemukakan ide-ide.

6) Memberikan motivasi-motivasi kepada siswa agar siswa lebih aktif dan semangat dalam pembelajaran.

\section{Siklus II}

Pembelajaran siklus II difokuskan pada materi perubahan lingkungan fisik yang disebabkan oleh banjir dan longsor dengan menggunakan pendekatan konstruktivisme. Untuk memperoleh data tentang pelaksanaan siklus II dilakukan pengamatan dan tes. Hasil pengamatan dan tes selama pelaksanaan tindakan dianalisis dan didiskusikan dengan pengamat sehingga diperoleh hal-hal sebagai berikut:

1) Pembelajaran yang dilaksanakan telah menggunakan pendekatan konstruktivisme di mana langkahlangkah pembelajaran yang diterapkan sesuai dengan langkah-langkah pembelajaran dengan menggunakan pendekatan konstruktivisme.

2) Hasil pengamatan yang dilakukan guru kelas IV selaku pengamat terhadap aktivitas peneliti sebagai guru dalam kegiatan pembelajaran pertemuan pertama siklus II ini mencapai kriteria keberasilan $90 \%$ yang berarti masuk kategori sangat baik dan kita lihat tingkat aktifitas siswa dalam kegiatan pembelajaran mencapai kriteria keberhasilan 88\%, ini berarti masuk kategori baik. Sedangkan hasil pengamatan pada pertemuan kedua siklus II, pengamatan terhadap kegiatan guru memperoleh skor 93\% yang termasuk dalam kategori sangat baik sedangkan pengamatan terhadap aktifitas siswa memperoleh skor $91 \%$ termasuk dalam kategori sangat baik.

3) Interaksi kelas sudah bagus, yaitu siswa sudah mau bertanya, siswa mau mengeluarkan pendapat.

4) Suasana kelas nampak hidup.

5) Diskusi kelompok dan diskusi kelas berjalan dengan lancar.

6) Hasil belajar siswa yang dicapai sudah mencapai ketuntasan belajar, di mana hasil tes akhir yang dilakukan pada siklus II didapatkan nilai rata-rata siswa adalah 83 dan secara klasikal siswa telah mencapai tingkat ketuntasan $86 \%$.

Dari analisis di atas, dapat disimpulkan pembelajaran pada siklus II ini telah berjalan sesuai dengan yang direncanakan. Hasil tes siklus II menunjukkan bahwa tingkat ketuntasan untuk kelas telah sesuai dengan apa yang diharapkan. Maka penelitian ini sudah dapat dikatakan berhasil.

\section{PEMBAHASAN}

Dari hasil penelitian pelaksanaan pembelajaran dengan menggunakan pendekatan konstruktivisme pada pembelajaran IPA kelas IV terungkap bahwa guru membuat rancangan pembelajaran dalam bentuk Rencana Pelaksanaan Pembelajaran (RPP). Susanto (2007:167) mengatakan bahwa: RPP adalah penjabaran silabus ke dalam unit satuan kegiatan pembelajaran untuk dilksanakan di kelas. Perencanaan yang disusun guru dalam penelitian terdiri dari beberapa komponen yaitu: 1) standar kompetensi, 2) kompetensi dasar, 3) indikator, 4) tujuan pembelajaran, 5) materi pokok, 6) proses pembelajaran, 7) media dan sumber, 8) penilaian. Standar 
kompetensi dan kompetensi dasar diambil dari kurikulum tingkat satuan pendidikan IPA kelas IV sekolah dasar.

Rencana Pelaksanaan Pembelajaran (RPP) ini dirancang berdasarkan langkah-langkah pembelajaran dengan menggunakan pendekatan konstruktivisme. RPP disusun berdasarkan program semester sesuai dengan waktu penelitian yang akan dilaksanakan. Standar kompetensi pembelajarannya adalah memahami perubahan lingkungan fisik dan pengaruhnya terhadap daratan, dengan kompetensi dasar "menjelaskan pengaruh perubahan lingkungan fisik terhadap daratan (erosi, abrasi, banjir dan longsor)".

Langkah-langkah kegiatan pembelajaran dalam RPP ini dibagi menjadi tiga tahap, yaitu kegiatan awal, kegiatan inti, dan kegiatan akhir. Adapun kompetensi dasar yang diambil dilaksanakan secara utuh yang terbagi menjadi empat kali pertemuan sesuai dengan banyak materi yang terdapat dalam kompetensi dasar (erosi, abrasi, banjir, dan longsor) sehingga dalam satu kompetensi tersebut tidak ada yang terpisah. Pada siklus I ini materi yang diambil adalah erosi dan abrasi yang dilaksanakan dalam 2 x pertemuan. Untuk melihat semua kegiatan pada pertemuan pertama dan kedua dapat dilihat dalam RPP pada siklus I.

Pelaksanaan pembelajaran pada siklus I sesuai dengan apa yang telah direncanakan, yang mana pada siklus I pembelajaran disajikan dalam dua kali pertemuan (4x35menit). Dalam suatu kegiatan pembelajaran siswa dikatakan telah belajar, apabila terjadi proses perubahan perilaku pada diri siswa sebagai hasil dari suatu pengalaman. Pelaksanaan pembelajaran dengan menggunakan pendekatan konstruktivisme merupakan proses membangun atau menyusun pengetahuan baru dalam struktur kognitif siswa berdasarkan pengalaman. Adapun pengalaman nyata yang diperoleh siswa yaitu dengan melakukan percobaan pada setiap pertemuannya.

Pembelajaran dengan pendekatan konstruktivisme bukanlah kegiatan memindahkan pengetahuan dari guru ke siswa, melainkan suatu kegiatan yang memungkinkan siswa membangun sendiri pengetahuannya, artinya Pendekatan konstruktivisme menempatkan siswa sebagai subjek belajar. Seluruh aktifitas yang dilakukan siswa dalam pendekatan konstruktivisme diarahkan untuk membangun konsep awal siswa terhadap materi dan memahami konsep tersebut salah atau benar setelah mengikuti pembelajaran.

Pembelajaran pada siklus I dilaksanakan sesuai dengan langkah-langkah pendekatan konstruktivisme yaitu pengaktifan pengetahuan yang sudah ada, pemerolehan pengetahuan baru, pemahaman pengetahuan, menerapkan pengetahuan dan pengalaman yang diperoleh, dan yang terakhir melakukan refleksi. Pelaksanaan pembelajaran pada siklus I belum berhasil karena kebiasaan siswa dalam belajar yang terbiasa menerima informasi dari guru sehingga siswa sulit untuk menyesuaikan diri dengan pendekatan konstruktivisme yang menuntut keaktifan siswa dalam pembelajaran sehingga pengetahuan awalnya yang telah dimilikinya dapat dibangun kembali berdasarkan materi yang baru dipelajarinya.

Pelaksanaan pembelajaran dengan menggunakan pendekatan konstruktivisme pada siklus I dilakukan di kelas IV SD Negeri 09 IV Koto Aur Malintang pada pembelajaran IPA dengan materi pengaruh perubahan lingkungan fisik terhadap daratan (erosi dan abrasi). Pendekatan konstruktivisme mengharapkan siswa dapat mengaitkan pembelajaran dengan kehidupan nyata yang dilalami sehari-hari. Akan tetapi, karena metode diskusi dan eksprimen belum biasa dilaksanakan dalam pembelajaran, maka sebagian siswa terlihat bingung dalam memulai pekerjaan.

Berdasarkan catatan pada lembar observasi dan diskusi peneliti dengan pengamat, penyebab dari masih rendahnya hasil belajar siswa pada siklus I adalah kurangnya kemampuan siswa dalam menerima pembelajaran sehingga kemampuan siswa dalam memahami soal men jadi kurang. Selain itu jumlah siswa yang banyak menyebabkan kegiatan siswa kurang terkontrol oleh guru ditambah lagi dengan pembagian duduk berkelompok masih banyak siswa yang tidak menerima anggota kelompok sebagaimana yang telah ditetapkan oleh guru.

Pencapaian hasil belajar siswa sebelum dan sesudah melaksanakan pembelajaran IPA dengan menggunakan pendekatan konstruktivisme pada siklus I sudah dikatakan baik dibanding sebelum diadakannya tindakan. Adapun penilaian yang dilakukan oleh guru meliputi tiga ranah penilaian yaitu aspek afektif dan aspek psikomotor (proses) serta aspek kognitif (hasil). Sedangkan untuk mengetahui hasil belajar siswa dalam pembelajaran IPA, guru menggunakan penilaian pada aspek kognitif (hasil) saja. Untuk lebih jelasnya akan dijabarkan satu persatu dari ketiga aspek tersebut.

Penilaian pada aspek afektif, persentase nilai rata- rata yang diperoleh siswa adalah $72 \%$ yang termasuk dalam kategori cukup. Hal ini disebabkan karena siswa belum terbiasa dengan penerapan pendekatan konstruktivisme dalam pembelajaran. Hal ini membuat siswa menjadi canggung, akibat perubahan drastis dari metode ceramah yang biasa digunakan guru. Walaupun perhatian siswa lebih fokus dalam pelajaran jika dibandingkan sebelum dilakukan tindakan, akan tetapi antusias siswa dalam belajar belum terlihat. Diskusi yang dilakukan juga membuat siswa bingung dengan apa yang akan dilakukan, akibatnya partisipasi dalam 
kelompok menjadi rendah dan siswa tidak memiliki keberanian untuk menyampaikan gagasan maupun pertanyaan kepada kelompok lain saat melakukan presentasi maupun diskusi kelas.

Penilaian aspek psikomotor pada siklus I ini persentase nilai rata- rata yang diperoleh oleh siswa adalah $75 \%$ dan termasuk dalam kategori cukup. Hal ini dapat dilihat pada kegiatan siswa yang belum terampil dalam menggunakan alat peraga, siswa kurang tekun dalam bekerja. Kerja sama dalam kelompok juga masih kurang, di mana siswa masih mengerjakan tugas yang diberikan guru secara individu. Hal ini dikarenakan siswa belum terbiasa belajar sambil bekerja akibat penggunaan ceramah yang sebelumnya dominan digunakan guru.

Penilaian kognitif siswa pada siklus I diperoleh rata-rata kelas sebesar 73. Nilai tertinggi adalah 100 dan nilai terendah 35. Hasil ketuntasan kelas: terdapat 22 siswa yang telah memperoleh ketuntasan, sementara 14 siswa belum mencapai ketuntasan minimal, sehingga diperoleh ketuntasan kelas sebesar $61 \%$. Belum diperolehnya hasil ketuntasan belajar secara maksimal dianalisa karena siswa masih takut dan ragu dalam mengajukan pertanyaan mengenai materi pelajaran yang belum dipahami.

Dari hasil penelitian pelaksanaan pembelajaran dengan menggunakan pendekatan konstruktivisme pada pembelajaran IPA kelas IV terungkap bahwa guru membuat rancangan pembelajaran dalam bentuk Rencana Pelaksanaan Pembelajaran (RPP). Perencanaan yang disusun guru dalam penelitian terdiri dari beberapa komponen yaitu: 1) standar kompetensi, 2) kompetensi dasar, 3) indikator, 4) tujuan pembelajaran, 5) materi pokok, 6) proses pembelajaran, 7) media dan sumber, 8) penilaian. Standar kompetensi dan kompetensi dasar diambil dari kurikulum tingkat satuan pendidikan IPA kelas IV Sekolah Dasar.

Rencana Pelaksanaan Pembelajaran (RPP) ini dirancang berdasarkan langkah-langkah pembelajaran dengan menggunakan pendekatan konstruktivisme. RPP disusun berdasarkan program semester sesuai dengan waktu penelitian yang akan dilaksanakan. Standar Kompetensi pembelajarannya adalah memahami perubahan lingkungan fisik dan pengaruhnya terhadap daratan, dengan Kompetensi Dasar Menjelaskan pengaruh perubahan lingkungan fisik terhadap daratan (erosi, abrasi, banjir dan longsor).

Pelaksanaan pembelajaran pada siklus II sesuai dengan apa yang telah direncanakan, di mana pada siklus II pembelajaran disajikan dalam dua kali pertemuan (4x35menit). Dalam suatu kegiatan pembelajaran siswa dikatakan telah belajar, apabila terjadi proses perubahan perilaku pada diri siswa sebagai hasil dari suatu pengalaman. Pelaksanaan pembelajaran dengan menggunakan pendekatan konstruktivisme merupakan proses membangun atau menyusun pengetahuan baru dalam struktur kognitif siswa berdasarkan pengalaman yang diperoleh melalui proses pembelajaran.

Pembelajaran dalam pendekatan konstruktivisme bukanlah kegiatan memindahkan pengetahuan dari guru ke siswa, melainkan suatu kegiatan yang memungkinkan siswa membangun sendiri pengetahuannya, artinya pendekatan konstruktivisme menempatkan siswa sebagai subjek belajar. Seluruh aktifitas yang dilakukan siswa dalam pendekatan konstruktivisme diarahkan untuk membangun konsep awal siswa terhadap materi dan memahami konsep tersebut salah atau benar setelah mengikuti pembelajaran.

Pembelajaran pada siklus II dilaksanakan sesuai dengan langkah-langkah pendekatan konstruktivisme yaitu pengaktifan pengetahuan yang sudah ada, pemerolehan pengetahuan baru, pemahaman pengetahuan, menerapkan pengetahuan dan pengalaman yang diperoleh, refleksi. Pelaksanaan pembelajaran pada siklus II sudah sempurna karena siswa dalam belajar telah bisa menerima informasi dari guru sehingga siswa tidak sulit untuk menyesuaikan diri dengan pendekatan konstruktivisme yang menuntut keaktifan siswa dalam pembelajaran dengan banyak bertanya sehingga dapat membangun pengetahuan awalnya terhadap materi pembelajaran dan lebih memahami dengan adanya tanggapan dari temannya.

Tahap pelaksanaan pembelajaran pada siklus II ini sama dengan langkah-langkah pada siklus I, perubahan dilakukan pada tahap pemerolehan pengetahuan baru adalah dengan materi yang berbeda sehingga lebih menarik minat dan rasa ingin tahu siswa terhadap materi yang akan dipelajarinya. Dalam diskusi kelompok pada siklus II ini siswa sudah bisa bekerja sama dengan baik.

Pelaksanaan pembelajaran dengan menggunakan pendekatan konstruktivisme pada siklus II dilakukan di kelas IV SDN 09 IV Koto Aur Malintang pada pembelajaran IPA dengan materi pengaruh perubahan lingkungan fisik terhadap daratan (banjir dan longsor). Pendekatan konstruktivisme mengharapkan siswa dapat mengaitkan pembelajaran dengan kehidupan nyata yang dialami sehari-hari. Akan tetapi, karena metode diskusi dan eksprimen belum biasa dilaksanakan dalam pembelajaran, maka sebagian siswa terlihat bingung dalam memulai pekerjaan.

Setelah diadakan refleksi dan perbaikan tindakan, maka pelaksanaan proses pembelajaran IPA dengan menggunakan pendekatan konstruktivisme pada siklus II mengalami peningkatan pada hasil pembelajaran. Guru mulai aktif dalam memberikan bimbingan kepada siswa dan meminta masing-masing kelompok untuk mempresentasikan hasil kerja masing-masing. Kelompok yang tidak mendapat giliran untuk presentasi diminta menanggapi hasil kelompok yang melakukan presentasi. 
Pada siklus II, pelaksanaan pembelajaran IPA dengan menggunakan pendekatan konstruktivisme mengalami peningkatan yang memuaskan. Rata-rata analisis hasil observasi pembelajaran dengan menggunakan pendekatan konstruktivisme pada siklus II mengalami kenaikan jika dibandingkan dengan ratarata pada siklus I, yaitu 83. Hal ini terlihat pada perhatian siswa dan antusias siswa dalam mengikuti proses pembelajaran. Pada saat pelaksanaan diskusi dan eksprimen, tugas yang diberikan kepada masing-masing kelompok langsung dikerjakan oleh siswa. Masing-masing kelompok dapat menyelesaikan tugas yang diberikan dengan waktu yang efektif sebagian besar siswa sudah mulai berani mengeluarkan pendapat tanpa diminta guru.

Untuk analisis penilaian afektif siswa selama siklus II diperoleh nilai 84. Hasil penelitian ini meningkat jika dibandingkan dengan penilaian aspek afektif pada siklus I. Kenaikan terjadi pada semua aspek yang diobservasi. Contohnya perhatian siswa terhadap pembelajaran IPA sudah meningkat, siswa lebih bergairah dan antusias dalam belajar, siswa mengikuti kegiatan kegiatan diskusi dengan semangat dan memiliki keberanian dalam mengungkapkan pendapat.

Analisis penilaian psikomotor siswa selama siklus II diperoleh nilai rata-rata keseluruhan 86. Hasil ini meningkat jika dibandingkan dengan hasil yang diperoleh pada siklus I. Peningkatan terjadi pada semua aspek yang diobservasi, seperti keterampilan siswa dalam menggunakan alat peraga menjadi lebih meningkat, siswa lebih tekun dalam bekerja, kritis, dan siswa sudah mampu menggunakan waktu secara efektif.

Analisis penilaian kognitif pada siklus II diperoleh nilai rata-rata kelas sebesar 83. Nilai tertinggi adalah 100 dan nilai terendah 55. Hasil ketuntasan kelas: 31 siswa telah memperoleh ketuntasan, sementara 5 siswa belum mencapai ketuntasan minimal, sehingga diperoleh ketuntasan kelas sebesar $86 \%$.

Dalam penilaian aspek kognitif, masih terdapat siswa 10 orang siswa yang mengalami penurunan nilai jika dibandingkan dengan nilai pada waktu tindakan pada siklus I. Hal ini disebabkan beberapa orang siswa yang bersangkutan sering meminta permisi keluar pada waktu pembelajaran berlangsung. Kemudian ada juga siswa yang mengatakan bahwa dia sudah merasa jenuh dalam kelompoknya karena anggota kelompoknya tetap sama, mulai dari pertemuan pertama siklus I sampai pertemuan kedua siklus II sehingga ia tidak lagi memperhatikan jalannya pembelajaran.

\section{KESIMPULAN DAN SARAN \\ KESIMPULAN}

Dari paparan dan hasil penelitian dan pembahasan dalam Bab IV, kesimpulan yang dapat diambil dari penelitian ini adalah sebagai berikut:

a. Rencana pelaksanaan pembelajaran dengan menggunakan pendekatan konstruktivisme dibagi dalam tiga tahap pembelajaran, yaitu kegiatan awal, inti, dan akhir. Pada kegiatan awal dilaksanakan dengan melakukan appersepsi, kegiatan inti direncanakan pembelajaran dengan menggunakan langkah-langkah konstruktivisme, serta pada kegiatan akhir dilaksanakan penyimpulan pelajaran dan pemberian evaluasi pada siswa.

b. Bentuk pelaksanaan pembelajaran IPA disesuaikan dengan langkah-langkah penggunaan pendekatan konstruktivisme adalah: pada kegiatan awal yaitu menentukan tujuan, pada kegiatan inti disesuaikan dengan langkah-langkah konstruktivisme yaitu: mengaktifkan pengetahuan yang ada, pemerolehan pengetahuan baru, pemahaman pengetahuan, menerapkan pengetahuan dan pengalaman yang diperoleh, serta refleksi. Dan pada kegiatan akhir yaitu tindak lanjut dan evaluasi sesuai dengan materi yang telah dibahas dalam pembelajaran.

c. Dengan menggunakan pendekatan konstruktivisme dalam pembelajaran IPA, hasil belajar siswa kelas IV SDN 09 IV Koto Aur Malintang sudah meningkat. Peningkatan ini dapat dilihat pada skor aspek afektif siswa pada siklus I adalah $72 \%$, siklus II meningkat menjadi $84 \%$. Skor aspek psikomotor siswa pada siklus I adalah 75\%, pada siklus II skor meningkat menjadi 86\%. Pada aspek kognitif, rata-rata skor siswa siklus I adalah 73, meningkat menjadi 83. Sedangkan tingkat ketuntasan pada siklus I mencapai $61 \%$, pada siklus II meningkat menjadi $86 \%$. Jumlah siswa yang mencapai ketuntasan pada siklus I sebanyak 22 orang, dan siklus II meningkat menjadi 31 siswa dari 36 orang siswa. Jadi jumlah siswa yang tidak tuntas ada 5 orang siswa.

\section{SARAN}

Berdasarkan kesimpulan yang telah diperoleh dalam penelitian ini, maka disarankan kepada:

a. Sekolah, hendaknya dapat memfasilitasi guru dalam mengembangkan berbagai inovasi dalam pembelajaran, sehingga dapat meningkatkan prestasi belajar siswa. 
b. Guru, hendaknya dapat melibatkan seluruh siswa untuk aktif dalam pembelajaran terutama dalam kegiatan diskusi kelompok sehingga dapat meningkatakan pengetahuan dan keterampilan siswa dalam memahami materi yang sedang dipelajari.

c. Siswa, hendaknya dapat terlibat aktif melaksanakan instruksi guru dalam kegiatan pembelajaran.

\section{DAFTAR PUSTAKA}

Alben Ambarita. (2006). Manajemen Pembelajaran. Jakarta: Depdiknas

Anita Yus. (2006). Penilaian Portofolio untuk Sekolah Dasar. Jakarta: Depdiknas

Asri Budiningsih. (2005). Belajar Dan Pembelajaran. Yogyakarta:Rineka Cipta.

Haryanto. (2006). Sains Untuk Sekolah Dasar Kelas IV.Jakarta: Erlangga.

I. G. A. K Wardhani,dkk. (2007). Penelitian Tindakan Kelas. Jakarta: UT

Joko Subagyo.(2006) Metode Penelitian dalam Teori dan Praktek. Jakarta: Rineka Cipta

Kemmis, S., dan Taggart, M.R. (1990). The Action Research Planner. Victoria: Deakin University.

Kunandar. (2007). Guru Propesional. Jakarta:Grafindo Persada

. (2008). Langkah Mudah Penelitian Tindakan Kelas sebagai Pengembangan Propesi Guru. Jakarta: PT. Raja Grafindo Persada.

Muhammad Nur, dkk. (1998). Pendekatan-Pendekatan Konstruktif dalam pembelajaran. Surabaya: Dikti

Mulyasa. (2007). Kurikulum Tingkat Satuan Pendidikan Sebuah Panduan Praktis. Bandung: PT Remaja Rosdakarya.

Muslichach Asy'ari. (2006). Penerapan Pendekatan Sains Teknologi Masyarakat dalam Pembelajaran Sains di SD. Jakarta: Dikti

Nono Sutarno. (2007). Materi dan Pembelajaran IPA SD. Jakarta: UT

Nurhadi, dkk. (2003). Pembelajaran Kontekstual Dan Penerapannya dalam KBK. Malang: Universitas Negeri Malang.

Oemar Hamalik. (1993). Proses Belajar Mengajar. Jakarta: Bumi Aksara

Paul Suparno. (1996). Filfilsafat Konstruktivisme dalam Pendidikan. Boston:Pustaka Filsafat.

Suharsimi Arikunto,dkk. (2008). Penelitian Tindakan Kelas.Jakarta: Bumi Aksara . (2007). Evaluasi Program Pendidikan. Jakarta: Bumi Aksara

Sumiati dan Asra. (2007). Metode Pembelajaran. Bandung: Wacana Prima

Susanto. (2007). Pengembangan KTSP dengan Perspektif Manajemen Visi. Jakarta: Mata

Syaiful Sagala. (2003). Konsep dan Makna Pembelajaran untuk Membantu Memecahkan Problematika Belajar dan Mengajar. Bandung: Alfabeta

Wina Sanjaya. (2007). Strategi Pembelajaran Beroriantasi Standar Proses Pendidikan. Jakarta: Kencana. 